\title{
Phytoprotection
}

\section{Inheritance of resistance to Kabatielle eyespot of maize}

\section{M.S. Chang, M. Hudon et A. Devaux}

Volume 71, numéro 3, 1990

URI : https://id.erudit.org/iderudit/705991ar

DOI : https://doi.org/10.7202/705991ar

Aller au sommaire du numéro

\section{Éditeur(s)}

Société de protection des plantes du Québec (SPPQ)l

\section{ISSN}

0031-9511 (imprimé)

1710-1603 (numérique)

Découvrir la revue

Citer cet article

Chang, M., Hudon, M. \& Devaux, A. (1990). Inheritance of resistance to Kabatielle eyespot of maize. Phytoprotection, 71(3), 107-112.

https://doi.org/10.7202/705991ar

\section{Résumé de l'article}

Des études génétiques portant sur la résistance du maïs-grain (Zea mays) aux attaques de la kabatiellose causée par le Kabatiella zeae ont consisté en des essais de croisements diallèles $8 \times 8$. Chez les huit lignées utilisées, l'action additive des gènes semble avoir été déterminante quant à la résistance aux attaques du feuillage. Il y a eu un certain degré de dominance chez quatre groupes de gènes. L'hérédité au sens strict a été évaluée à $75 \%$. La lignée V312 a été la plus résistante à la maladie tandis que les lignées F522, WF9 et L2039 sont apparues sensibles. 


\title{
Inheritance of resistance to Kabatiella eyespot of maize
}

\author{
M.S. Chiang, M. Hudon
}

Research Station, Agriculture Canada, 430 Gouin blvd.

Saint-Jean-sur-Richelieu, Québec, Canada J3B 3E6. Contribution $N^{\circ}$ 335/90.10.24R.

\section{A. Devaux}

Research Station, Ministère de l'Agriculture, des Pêcheries et de l'Alimentation du Québec, P.O. Box 480, Saint-Hyacinthe, Québec, Canada J2S 7B8

(Received 1989-07-24; accepted 1990-04-23)

Genetic studies of resistance to Kabatiella zeae causing eyespot in grain maize (Zea mays) were conducted using an $8 \times 8$ complete diallel cross. In the eight inbreds used, the additive component appeared to be the most important in determining resistance to eyespot. There appeared to be at least four genes showing some degree of dominance. Narrow-sense heritability was estimated at $75 \%$. Inbred V312 was the most resistant line among the eight lines in this diallel set, whereas F522, WF9 and L2039 appeared to be susceptible.

Chiang, M.S., M. Hudon, and A. Devaux. 1990. Inheritance of resistance to Kabatiella eyespot of maize. PHYTOPROTECTION 71: 107-112.

Des études génétiques portant sur la résistance du maïs-grain (Zea mays) aux attaques de la kabatiellose causée par le Kabatiella zeae ont consisté en des essais de croisements diallèles $8 \times 8$. Chez les huit lignées utilisées, l'action additive des gènes semble avoir été déterminante quant à la résistance aux attaques du feuillage. Il y a eu un certain degré de dominance chez quatre groupes de gènes. L'hérédité au sens strict a été évaluée à $75 \%$. La lignée V312 a été la plus résistante à la maladie tandis que les lignées F522, WF9 et L2039 sont apparues sensibles.

\section{Introduction}

The origin of the fungus (Kabatiella zeae Narita and Hiratsuka) that causes eyespot disease remains unknown and seems more specific to maize (Reifschneider and Arny 1980). It was first described in Japan by Narita and Hiratsuka (1959). This foliar disease spread rapidly in many areas in the world during the late 60's to the early 70's. It appeared over a wide aréa of north central United States in 1968 (Arny et al. 1971; Epstein and Nyval 1971; Grau et al. 1982; Ullstrup et al., 1969), in Canada (Gates and Mortimore 1969), in the Federal Republic of Germany (Schneider and Krüger 1972), in France (Cassini 1971, 1973), in Argentina (Frezzi 1972), in New Zealand (Dingley 1973), in Hungary (Hausz and Fischl 1977), in Yugoslavia (Penčić and Rozenfeld 1979), and in Poland (Czaplinska 1981). In Québec, it was first observed in 1974 by Chez and Hudon (1975).
Leaf diseases affect maize plant growth severely by reducing sugar production in affected leaves and resulting in lower kernel weight and decreased yield of 1.7 to $14.5 \%$ (Levic 1987). Reifschneider and Arny (1983b) estimated a $9 \%$ grain yield reduction due to the natural occurrence of this disease in Wisconsin. Furthermore, silage made with diseased leaves would have less nutritional value than silage made with healthy ones (Sutton 1981). Eyespot disease is widely distributed in Ontario and Québec, and develops most severely in fields which had large amounts of surface maize debris left in the field from previous seasons. The fungus survives the winter and is spread by rain splashes and wind to the leaves in early summer when plants are at the whorl stage. Occasional lesions have been found on maize seedlings in late May. In Québec, heavy infections normally does not become severe until August. Under humid and cool weather the disease may cause extensive leaf blight and affect the grain yield significantly.

Reifschneider and Arny (1983a) suggested that inheritance to $K$. zeae in maize is partially dominant and qualitatively inherited 
based on conventional method involving $F_{2}$ and backcross populations. More recently, Levic (1987) studied the inheritance of resistance to this disease by means of a $10 \times 10$ diallel cross, and concluded that although both additive and dominance gene action played an important role in the inheritance, the former gene action is more important. It is important to understand the genetic nature of resistance to $K$. zeae in more inbred lines so that suitable lines and proper breeding methods can be chosen. This present paper reports on the inheritance of resistance to eyespot caused by $K$. zeae in maize by means of an $8 \times 8$ complete diallel cross.

\section{Materials and methods}

Eight maize inbred lines with different levels of resistance and susceptibility to $K$. zeae were chosen for this diallel cross. The sources of seeds were listed as follows: V312, K44 and L2039 (Beograd, Yugoslavia), F522 (France), B37, Oh43, W64A and WF9 (Wisconsin, U.S.A.). The days to silking and resistance/tolerance to the European corn borer (Ostrinia nubilalis [Hübner]) of those lines were reported by Hudon et al. (1979) and Hudon and Chiang (1985). The inbreds were intercrossed in all possible combinations for an $8 \times 8$ complete diallel test. A randomized complete block design with four replications was used. Each block contained the eight parental lines and the $56 \mathrm{~F}_{1}$ (including reciprocals) populations. Seeds were planted on 14 May 1988, at the L'Acadie Farm of Saint-Jean-sur-Richelieu Research Station, Québec. Single-row plots were sown with two seeds every $30 \mathrm{~cm}$ within the row, each row contained 10 hills. Rows were spaced at $90 \mathrm{~cm}$. The stand was later thinned to one plant per hill.

All plants were artificially inoculated twice with $K$. zeae, on the same day at threeday-intervals in the field using both the following methods:

Inoculation via sorghum (Sorghum vulgare Pers.) seeds. One kilogram of sorghum seeds (about 35000 seeds) were soaked in distilled water for overnight and autoclaved for $30 \mathrm{~min}$. Seeds were then shaken vigorously before a 30 -min steriliza- tion. This procedure was repeated three times. Sterilized seeds were inoculated with $250 \mathrm{~mL}$ of spore suspension (40000 spores $/ \mathrm{mL}$ ) of $K$. zeae isolated from eyespot lesions the previous season on diseased maize leaves in the field and incubated for 7 days at room temperature. Seeds were shaken daily during the incubation period to prevent cake formation and were then ready to inoculate the plants. Five to seven inoculated sorghum seeds were deposited into the whorl of each plant for the first inoculation.

Inoculation by spraying. Three days after the sorghum seed inoculation, a spore suspension of $K$. zeae (40000 spores $/ \mathrm{mL}$ ) was sprayed on the leaf surface of the whorl using a small garden hand sprayer (Solo 455 ) having a pressure of $1 \mathrm{kPa} / \mathrm{m}^{2}$. The liquid inoculum preparation was similar to that described by Reifschneider and Arny (1979).

The percentage of leaf area covered with eyespot for each plant was rated at 3 to 4 weeks after pollination, normally at the end of August before the leaves shrunk. Disease intensity on the individual plant was rated according to a scale of 1 to 12 , where $1=$ no apparent symptoms on the leaf and $12=$ the whole leaf was visibly completely covered (Horsfall and Barratt 1945). Plot means were used for statistical calculations.

Statistical analyses were performed according to the method of Hayman (1954a, 1954b). The following symbols were used in the analysis of variance of diallel tables:

$a=$ genetic variation among parents;

$b=$ dominance at some of the loci;

$b_{1}=$ mean dominance deviation (difference between the parental mean and the progeny mean);

$b_{2}=$ asymmetry of the gene distribution at the loci exhibiting dominance;

$b_{3}=$ discrepancy in reciprocals due to dominance;

$c=$ average maternal effects of parents;

$d=$ variation in reciprocal differences excluding maternal effects.

In order to estimate the components of variation, D (additive effects of genes), $\mathrm{H}_{3}$ (dominance effects of genes), $\mathrm{h}^{2}$ (dominance effects over all loci), $\mathrm{F}$ (covariation of additive and dominance effects), $\mathrm{H}_{2}$ 
(dominance indicating asymmetry of positive and negative effects of genes), the following statistics were calculated from the data for each block separately:

$\mathrm{W}_{\mathrm{r}}=$ covariance between the parents and their offspring in $\mathrm{r}^{\text {th }}$ array;

$\mathrm{V}_{\mathrm{r}} \quad=$ variance of $\mathrm{r}^{\text {th }}$ array;

$\mathrm{V}_{0 \mathrm{~L} 0}=$ variance of the parents;

$\mathrm{W}_{0 \mathrm{~L} 01}=$ covariance between the parents and the mean of their offspring;

$\mathrm{V}_{0 \mathrm{~L} 1}=$ variance of array means;

$\mathrm{V}_{1 \mathrm{Ll}}=$ mean variance of arrays.

Narrow-sence heritability ( $\mathrm{n}-\mathrm{s} \mathrm{h}$ ) was calculated by the formula of Crumpacker and Allard (1962):

$n-s h=\frac{1 / 4 D}{1 / 4 D+1 / 4 H_{1}-1 / 4 F+E}$

where E represents the environmental components of variation.

\section{Results and discussion}

An analysis of variance of $\left(\mathrm{W}_{\mathrm{r}}-\mathrm{V}_{\mathrm{r}}\right)$ was used to test the validity of the assumptions in the genetic model. The F-value for lines was not significant, thus the uniformity of $\left(\mathrm{W}_{\mathrm{r}}-\mathrm{V}_{\mathrm{r}}\right)$ indicated the validity of the assumptions postulated by Hayman (1954b). The analysis of variance of diallel tables and the components of variation are presented in Tables 1 and 2, respectively. The high significance of $a$ indicates genetic variation among the parental lines. This agrees with the significance of the genetic component $\mathrm{D}$ which is the measure of variation due to additivity. Component $a$ is the magnitude of general combining ability and

Table 1. Analysis of variance of diallel tables

\begin{tabular}{lccc}
\hline Source & $\begin{array}{c}\text { Degree of } \\
\text { freedom }\end{array}$ & $\begin{array}{c}\text { Sum of } \\
\text { square }\end{array}$ & $\begin{array}{c}\text { Mean } \\
\text { square }\end{array}$ \\
\hline$a$ & 7 & 480.91 & $68.70^{* *}$ \\
$b$ & 28 & 105.53 & $3.77^{* *}$ \\
$b_{1}$ & 1 & 56.43 & $56.43^{* *}$ \\
$b_{2}$ & 7 & 15.58 & $2.23^{* *}$ \\
$b_{3}$ & 20 & 33.52 & $1.68^{*}$ \\
$c$ & 7 & 1.85 & $0.26 \mathrm{NS}$ \\
$d$ & 21 & 36.84 & $1.75^{*}$ \\
Block & 3 & 3.70 & $1.23 \mathrm{NS}$ \\
Error & 189 & 117.51 & 0.62 \\
Total & 255 & 746.35 & \\
\hline
\end{tabular}

* Significant at $\mathrm{P} \leq 0.05$; ** Significant at $P \leq$ $0.01 ; \mathrm{NS}$, non-significant.
Table 2. Genetic components for resistance to Kabatiella zeae among eight maize inbred lines

\begin{tabular}{cc}
\hline Component & Estimate and standard error \\
\hline $\mathrm{D}$ & $5.47^{* *} \pm 0.10$ \\
$\mathrm{H}_{1}$ & $2.75^{* *} \pm 0.23$ \\
$\mathrm{H}_{2}$ & $2.37^{* *} \pm 0.20$ \\
$\mathrm{~h}^{2}$ & $7.99^{* *} \pm 0.13$ \\
$\mathrm{~F}$ & $1.62^{* *} \pm 0.24$ \\
$\mathrm{E}$ & $0.16^{* *} \pm 0.03$ \\
$\mathrm{D}-\mathrm{H}_{1}$ & $2.72^{* *} \pm 0.20$ \\
\hline
\end{tabular}

** Significant at $P \leq 0.01$.

is recognized as primarily a measure of additive gene action. The high level of significance of $a$ and $\left(\mathrm{D}-\mathrm{H}_{1}\right)$ suggested that the additivity in the inheritance of resistance to eyespot plays an important role.

The significance of $b$ indicated that some of the loci responsible for the resistance to the pathogen showed dominance. The presence of dominance effects was also evident from the significance of dominance components $\mathrm{H}_{1}, \mathrm{H}_{2}$ and $\mathrm{h}^{2}$. Variance $b$ measures the specific combining ability which is regarded as an estimate of the effects of nonadditive gene action. However, the mean square ratio of $a / b=68.70 / 3.77=$ 18.22 , indicating that additive gene action is 18 times greater than dominance. The significance of $b_{1}$ suggested that the partial dominance effects are largely unidirectional. Since the progeny mean $(4.81)$ is smaller than the parental mean (6.23), resistance to eyespot was partially dominant over susceptibility. The significance of $b_{2}$ indicated asymmetry of the gene distribution at the loci exhibiting dominance and the significance of $b_{3}$ indicated discrepancy in reciprocals due to dominance.

No maternal inheritance was involved as indicated by the non-significance of $c$. However, there was reciprocal difference among some $F_{1}$ 's suggested by the significance of $d$ value. In this diallel cross, all crosses were not statistically different from their respective reciprocals except cross K44 × L2039 and its reciprocal. According to Wearden (1964), if the variances of $a, b, c$ and $d$ are significant, further tests namely, $a$ against $c$ and $b$ against $d$, should be made. In the present study, $c$ was not statistically significant indicating that $a$, the additive genetic variation, was truly 
important. The mean square ratio of $b / d=$ $3.77 / 1.75=2.15 *($ d.f. $=28$ and 21$)$ also confirms the importance of dominance which was in the direction of resistance. The sign of $F$ component indicates the relative frequencies of dominant and recessive alleles in the parents. The sign of $F$ value in the present study is positive indicating that there was an excess of dominant alleles distributed among the parental lines.

The quantity of $\left(\mathrm{H}_{1} / \mathrm{D}\right)^{0.5}$ measures the degrees of dominance over all loci, and the value of this estimate is 0.71 (Table 3 ) which is smaller than 1 indicating partial dominance. The term of $\mathrm{H}_{2} / 4 \mathrm{H}_{1}$ provides an estimate of the average product of frequency $u v$ with positive (dominance) $u$ versus negative (recessive) $v$ alleles in the parents, and where $u+v=1$. It has a maximum value of 0.25 when $u=v=0.5$. The value of this estimate in the present study is 0.22 (Table 3 ), thereby indicating that the dominant and recessive alleles were not equally distributed among the parents. Similar information was indicated also from the level of significance of $b_{2}$ (Table 1).

The ratio of $\mathrm{K}_{\mathrm{d}} / \mathrm{K}_{\mathrm{r}}$ provides the estimate of the ratio between the total number of dominant to recessive genes in all the parents. The positive sign of the ratio indicates an excess of dominant genes and the negative sign, an excess of recessive genes. The ratio is 1.53 and again suggests that there is an excess of dominant genes among the parents. The ratio $h^{2} / \mathrm{H}_{2}$ estimates the number of groups of genes controlling a character exhibiting some dominance. The estimate of 3.37 (Table 3) indicated that there were at least four major gene groups involved in the control of resistance to eyespot in this set of inbred lines. This was in agreement with the estimate of $\mathrm{K}$ factors

Table 3. Ratios of genetic components and heritability for resistance to Kabatiella zeae among eight inbred lines

\begin{tabular}{lc}
\hline Expression & Ratio \\
\hline$\left(\mathrm{H}_{1} / \mathrm{D}\right)^{0.5}$ & 0.71 \\
$\mathrm{H}_{2} / 4 \mathrm{H}_{1}$ & 0.22 \\
$\mathrm{~K}_{\mathrm{d}} / \mathrm{K}_{\mathrm{r}}$ & 1.53 \\
$\mathrm{~h}^{2} / \mathrm{H}_{2}$ & 3.37 \\
$\mathrm{~K}=\left(\overline{\mathrm{F}}_{1}-\overline{\mathrm{P}}\right)^{2} /\left(1 / 4 \mathrm{H}_{2}\right)$ & 3.40 \\
Heritability & $76 \%$ \\
\hline
\end{tabular}

(3.40) (Table 3). Reifschneider and Arny (1983a) concluded that there were only two genes involved in the inheritance of resistance to eyespot, but this was estimated from only two crosses between susceptible and resistant lines.

The value of the correlation coefficient between the parental performance $\left(\mathrm{Y}_{\mathrm{r}}\right)$ and the corresponding values of order of dominance $\left(\mathrm{W}_{\mathrm{r}}+\mathrm{V}_{\mathrm{r}}\right)$ is highly significant $\left(r=0.88^{* *} ; 6\right.$ d.f.) (Table 4$)$. The order of parental performance rating was $1,2,3,4$, $5,6,7$, and 8 (most resistant line to most susceptible) whereas the order of dominance $\left(\mathrm{W}_{\mathrm{r}}+\mathrm{V}_{\mathrm{r}}\right)$ among the lines was 1, 3, 2, 5, $4,8,7$, and 6 . It was apparent that line 1 (V312) carried most of the dominant genes and that resistance was a partially dominant character.

Table 4. Order of dominance and parental performance for resistance among eight maize inbred lines

\begin{tabular}{lcc}
\hline Parental line & $\begin{array}{c}\text { Parental } \\
\text { performance }\end{array}$ & $\begin{array}{c}\text { Order of } \\
\text { dominance } \\
\left(\mathrm{W}_{\mathrm{r}}+\mathrm{V}_{\mathrm{r}}\right)\end{array}$ \\
\hline (1) V312 & 3.6 & 2.38 \\
(2) K44 & 4.1 & 2.64 \\
(3) B37 & 4.1 & 2.61 \\
(4) Oh43 & 5.3 & 4.72 \\
(5) W64A & 6.0 & 3.68 \\
(6) F522 & 8.3 & 6.16 \\
(7) WF9 & 8.5 & 5.34 \\
(8) L2039 & 9.8 & 5.24 \\
\hline
\end{tabular}

$\S$ Parental performance was measured on a scale of 1 to 12 of eyespot (Horsfall and Barratt 1945).

Inbred line B37 had a low eyespot rating of 4.1 (Table 4). It also had the lowest array mean rating among this set of inbred lines. The average $F_{1}$ rating of the cross between V312 and B37 (and reciprocal) was 3.40 which is lower than the two parental ratings (Table 4). Thus, B37 apparently has gene(s) responsible for eyespot resistance which may not exist in line V312. According to Zuber (1975), B37 was one of the top three inbred lines widely used as a base of maize germplasm in the United States. This line has been tested against the European corn borer for 3 years at L'Acadie Farm, Québec, and results showed that it was rather tolerant to the corn borer (Hudon et al. 1979). Based on the above facts, B37 should 
be selected for a breeding program for resistance to eyespot. Although B37 is late for maturity under Québec's conditions, this problem can be easily overcome by planting it early in a greenhouse and then transplanted in the field to synchronize pollination with early lines.

The narrow-sense heritability of $76 \%$ fits into the high category according to Robinson (1966) suggesting that additive genetic variation contributed a considerable portion of the phenotypic variation. Reifschneider and Arny (1983a) estimated the broad-sense heritability at $77 \%$ in one cross and $78 \%$ in the other.

Because of the relative high heritability and the significance of additive gene action, the degree of resistance to eyespot should be easily improved either by phenotypic recurrent selection or simply by mass selection. However, as Lewis (1970) pointed out that it requires several such diallel analyses to identify a sufficiently large number of parental lines for developing a satisfactory germplasm pool from which recurrent or mass selection can be initiated.

The authors wish to thank Dr. F.J.F. Reifschneider of the University of Wisconsin for supplying inbred lines Oh43 and W64A and Dr. Viktorija Penčić of the Maize Research Institute of Zemun Polje (Beograd) Yugoslavia, for providing inbred lines L2039, V312 and $\mathrm{K} 44$. We also acknowledge the technical assistance of Mario Boivin of the Saint-Jean-sur-Richelieu Research Station and the cooperation of G.E. Waldron and R.I. Buzzell of the Harrow Research Station and Dr. R.I. Hamilton of the Ottawa Research Station for making some of the crosses.

Arny, D.C., E.B. Smalley, A.J. Ullstrup, G.L. Worf, and R.W. Ahrens. 1971. Eyespot of maize, a disease new to North America. Phytopathology 61: 54-57.

Cassini, R. 1971. Helminthosporium maydis race $\mathrm{T}$ et Kabatiella zeae, deux agents pathogènes du maïs nouveaux en France. Bull. Tech. Inf. 264-265: 1067-1072.

Cassini, R. 1973. État actuel des principales maladies du maïs. Phytiatr. Phytopharm. Rev. Fr. Med. Pharm. Vég. 22: 7-18.

Chez, D., and M. Hudon. 1975. La Kabatiella zeae, un nouvel agent pathogène du maïs à Québec. Phytoprotection 56: 90-95.

Crumpacker, D.W., and R.W. Allard. 1962. A diallel cross analysis of heading date in wheat. Hilgardia 32 : 275-318.
Czaplinska, S. 1981. [Les petites taches foliaires causées par Kabatiella zeae Narita et Hiratsuka, menacent les cultures de maïs] (in Polish). Ochr. Rostl. 25: 11-12.

Dingley, J.M. 1973. "Eyespot” disease of maize in New Zealand. N.Z. J. Agric. Res. 16: 325-338.

Epstein, A.H., and R.F. Nyval. 1971. Corn leaf diseases. Iowa State Univ. Coop. Ext. Serv. Pamphlet 507, 4 pp.

Frezzi, M.J. 1972. [Eyespot of maize (Kabatiella zeae) and yellow leaf blight (Phyllosticta zeae) of maize leaf in Argentina] (in Spanish). Rev. Agric. Livest. Res. Ser. 5, Plant Pathol. 9: 101-109.

Gates, L.F., and C.G. Mortimore. 1969. Three diseases of corn (Zea mays), new to Ontario: crazytop, a Phyllosticta leaf spot and eyespot. Can. Plant Dis. Surv. 49: 128-131.

Grau, C.R., M.F. Heimann, and D.C. Arny. 1982. Eyespot of corn. Univ. Wis. Coop. Ext. Prog. A3175, 2 pp.

Hausz, M., and G. Fischl. 1977. [Data to the occurrence of Kabatiella zeae Narita and Hiratsuka in Hungary] (in Hungarian). Novenyvedelem 13: 149-151.

Hayman, B.I. 1954a. The analysis of variance of diallel tables. Biometrics 10: 235-244.

Hayman, B.I. 1954b. The theory of analysis of diallel crosses. Genetics 39: 789-809.

Horsfall, J.G., and R.W. Barratt. 1945. An improved grading system for measuring plant diseases. Phytopathology 35: 655 (Abstract).

Hudon, M., and M.S. Chiang. 1985. Resistance and tolerance of maize germplasm to the European corn borer Ostrinia nubilalis (Hübner) and its maturity in Québec. Maydica 30: 329-337.

Hudon, M., M.S. Chiang, and D. Chez. 1979. Resistance and tolerance of maize inbred lines to the European corn borer Ostrinia nubilalis (Hübner) and their maturity in Québec. Phytoprotection 60: $1-22$.

Levic, J. 1987. [Inheritance of maize leaf resistance to Kabatiella zeae Narita and Hiratsuka and screening for sources of resistance] (in Serbo-Croatian). Arh. Poljopr. Nauke 48: 173-203.

Lewis, J. 1970. Reproductive growth in Lolium. 1. Evaluation of genetic differences within an established variety by means of a diallel cross. Euphytica 19: 470-479.

Narita, T., and Y. Hiratsuka. 1959. Studies on Kabatiella zeae n.sp., the causal fungus of a new leaf spot disease of corn. Ann. Phytopathol. Soc. Jpn. 24: 147-153.

Penčić, V., and J. Rozenfeld. 1979. [Étude des effets de Kabatiella zeae Narita et Hiratsuka sur le maïs] (in Serbo-Croatian). Zast. Bilja 30: 241-248.

Reifschneider, F.J.B., and D.C. Arny. 1979. A liquid medium for the production of Kabatiella zeae conidia. Can. J. Microbiol. 25: 1100-1102.

Reifschneider, F.J.B., and D.C. Arny. 1980. Host range of Kabatiella zeae causal agent of eyespot of maize. Phytopathology 70: 485-487.

Reifschneider, F.J.B., and D.C. Arny. 1983a. Inheritance of resistance in maize to Kabatiella zeae. Crop Sci. 23: 615-616.

Reifschneider, F.J.B., and D.C. Arny. 1983b. Yield loss of maize caused by Kabatiella zeae. Phytopathology 73: 607-609. 
Robinson, H.F. 1966. Quantitative genetics in relation to breeding on the Centennial of Mendelism. Indian J. Genet. 26(A): 171-187.

Schneider, R., and W. Krüger. 1972. [Kabatiella zeae Narita et Hiratsuka comme agent pathogène de taches foliaires du maïs en Allemagne] (in German). Phytopathol. Z. 73-74: 238-248.

Sutton, J.C. 1981. Leaf diseases of field corn. Ont Min. Agric. Food, Factsheet 81-009, 4 pp.
Ullstrup, A.J., E.B. Smalley, G.L. Worf, and R.W. Ahrens. 1969. Eyespot: a serious new disease of corn in the United States. Phytopathology 59: 1054 (Abstract).

Wearden, S. 1964. Alternative analysis of the diallel cross. Heredity 19: 669-681.

Zuber, M.S. 1975. Corn germplasm base in the U.S. - is it narrowing, widening, or static? Corn and Sorghum Res. Conf. 30: 277-286. 